University of Nebraska - Lincoln

DigitalCommons@University of Nebraska - Lincoln

Faculty Papers and Publications in Animal

Science

Animal Science Department

May 1984

\title{
RELATIONSHIPS AMONG MEASURES OF TESTICULAR DEVELOPMENT AND ENDOCRINE FUNCTION IN BOARS
}

\author{
A. P. Schinckel \\ University of Nebraska-Lincoln \\ R. K. Johnson \\ University of Nebraska-Lincoln, rjohnson5@unl.edu \\ R. J. Kittock \\ University of Nebraska-Lincoln
}

Follow this and additional works at: https://digitalcommons.unl.edu/animalscifacpub

Part of the Animal Sciences Commons

Schinckel, A. P.; Johnson, R. K.; and Kittock, R. J., "RELATIONSHIPS AMONG MEASURES OF TESTICULAR DEVELOPMENT AND ENDOCRINE FUNCTION IN BOARS" (1984). Faculty Papers and Publications in Animal Science. 37.

https://digitalcommons.unl.edu/animalscifacpub/37

This Article is brought to you for free and open access by the Animal Science Department at DigitalCommons@University of Nebraska - Lincoln. It has been accepted for inclusion in Faculty Papers and Publications in Animal Science by an authorized administrator of DigitalCommons@University of Nebraska - Lincoln. 


\title{
RELATIONSHIPS AMONG MEASURES OF TESTICULAR DEVELOPMENT AND ENDOCRINE FUNCTION IN BOARS ${ }^{1}$
}

\author{
A. P. Schinckel ${ }^{2}$, R. K. Johnson ${ }^{3}$ and R. J. Kittok ${ }^{3}$ \\ University of Nebraska, \\ Lincoln 68583
}

\begin{abstract}
Summary
Nine blood samples were taken at $30-\mathrm{min}$ intervals from 36 Landrace $\times$ Large White boars at each of eight ages $(42,56,70,84,98,112$, 126 and $140 \mathrm{~d})$. Serum concentrations of luteinizing hormone ( $\mathrm{LH})$, follicle-stimulating hormone (FSH), testosterone (T) and estradiol$17 \beta\left(\mathrm{E}_{2}\right)$ were quantified by radioimmunoassay procedures. The maximum concentration of $\mathrm{LH}$ and the age at maximum concentration were predicted for each boar. Variability of LH samples was described for each boar by the pooled within age variance among LH samples and by the number of LH peaks. Measurements of testicular development taken at $140 \mathrm{~d}$ of age included: in situ testis width and length, excised testis weights and histological traits of excised testes (seminiferous tubule diameter, percentage of tubules with a lumen and percentage of tubules with active spermatogenesis). Pooled within line correlations were calculated with data from boars selected for either high or low testis weight. Correlations among the testicular traits ranged from .45 to .88 . Luteinizing hormone concentration (mean over all ages) was related to measures of testicular development ( $r=.24$ to .49 ). Concentrations of $\mathrm{LH}$ from 42 to $84 \mathrm{~d}$ of age were more highly correlated with testicular traits than were the concentrations from 98 to $140 \mathrm{~d}$. Boars with larger, more mature testes tended to have higher maximum concentrations of LH $(r=.19$ to .42 ) and younger age at maximum concentration ( $\mathrm{r}=-.12$ to -.26$)$. Testicular traits were correlated with the number of LH peaks $(r$
\end{abstract}

\footnotetext{
${ }^{1}$ Published as Paper No. 7144 Journal Series, Nebraska Agr. Exp. Sta., Lincoln.

${ }^{2}$ Present address: Anim. Sci. Dept., Lilly Hall, Purdue Univ., West Lafayette, IN 47907.

${ }^{3}$ Anim. Sci. Dept., Univ. of Nebraska, Lincoln.

Received April 8, 1983.

Accepted October 5, 1983.
}

$=.31$ to .43 ) but not with $\mathrm{LH}$ sample variance $(\mathrm{r}=-.14$ to -.01$)$. Concentration of FSH was not related $(\mathrm{r}=-.20$ to .19$)$ to measures of testicular development. Testicular traits were more highly correlated with $\mathrm{E}_{2}$ concentration $(\mathrm{r}=.22$ to .41$)$ than with $\mathrm{T}$ concentration $(\mathrm{r}=$ .12 to .33 ). Correlations between gonadotropin and steroid concentrations were small and nonsignificant.

(Key Words: Swine, Testis Size, Luteinizing Hormone, Follicle-Stimulating Hormone, Testosterone, Estradiol-17 $\beta$.)

\section{Introduction}

Reproductive traits affect efficiency of swine production. However, selection has not been widely practiced for reproductive traits because they have low heritabilities. A moderately heritable trait, measurable on males and related to female reproduction would be useful in selection for increased female reproductive performance.

Gonads of both sexes have similar hormonal control systems (Land and Carr, 1979). Testicular development, spermatogenesis and steroid production in the male are controlled by follicle-stimulating hormone (FSH) and luteinizing hormone $(\mathrm{LH})$, which have parallel roles in controlling ovarian function. Evidence suggests that the same autosomal genes control these hormones in both sexes. Male and female mice from a line selected for high induced ovulation rate had increased gonadal sensitivity to FSH (Wolfe et al., 1981). Ewes and rams of the Finnish Landrace breed were less sensitive to negative feedback of steroids and had earlier pubertal releases of $\mathrm{LH}$ than did those of other, less prolific breeds (Land and Lee, 1976).

Selection for testis size, possibly in combination with measures of reproductive hormone concentrations, may alter endocrine systems such that reproductive performance will be 
improved. The objective of this study was to estimate the relationships between measures of testicular growth and reproductive hormone concentrations in boars.

\section{Materials and Methods}

Thirty-six Landrace $x$ Large White cross boars were selected from litters with either high or low predicted genetic merit for 150-d paired testis weight. Details of selection of 16 boars with low testis weight (LTW) and 20 boars with high testis weight (HTW), boar management, data collection and data analyses were previously described (Schinckel et al., 1984). Determination of luteinizing hormone ( $\mathrm{LH})$, folliclestimulating hormone (FSH), testosterone (T) and estradiol-17 $\beta\left(\mathrm{E}_{2}\right)$ concentrations were made at eight ages $(42,56,70,84,98,112,126$ and $140 \mathrm{~d}$ ). At $140 \mathrm{~d}$ of age, in situ testis width and length measurements were taken, boars were probed for backfat thickness, castrated and testis and epididymis weights were determined. Testicular tissue samples were fixed for $24 \mathrm{~h}$ in Bouins fluid and then transferred to $70 \%$ ethanol. Fixed tissues were embedded in paraffin wax and $5-\mu \mathrm{m}$ sections were stained with hematoxylin-eosin. Mean seminiferous tubule diameter was calculated from the measurement of 40 round tubules/boar. The percentage of tubules with a lumen and with active spermatogenesis (presence of spermatids) was estimated from the evaluation of 100 tubules/boar.

Nine blood samples were taken at 30-min intervals via jugular venipuncture at each age. A composite sample for each boar was made from the samples collected each day. Serum hormone concentrations were quantified by radioimmunoassay procedures. Luteinizing hormone concentrations were determined for individual samples and $\mathrm{T}, \mathrm{E}_{2}$ and FSH concentrations were determined on the pooled samples.

The maximum LH concentration and age at maximum concentration were predicted for each boar by periodic regression equations and were treated as new statistics. Variability of the LH samples was described for each boar by the pooled within age sample variance and by the number of peaks between 42 and $140 \mathrm{~d}$. A peak was defined as a sample whose lower $66 \%$ confidence limit was higher than the upper $66 \%$ confidence limits for the preceding and subsequent samples.

Correlations among variables were estimated from the residual variances and covariances obtained from least-squares analysis. The model included the fixed effects of line, farrowing group and line $x$ farrowing group. Data analyzed included testicular measurements, body weight and backfat thickness taken at $140 \mathrm{~d}$ of age and hormone concentrations from 42 to $140 \mathrm{~d}$. Four sets of correlations were calculated: (1) among measures of testicular development, (2) among concentrations of gonadotropins, (3) between measures of testicular development and concentrations of gonadotropins and (4) between concentrations of steroids with measures of testicular development and with concentrations of gonadotropins.

\section{Results}

Correlations among testicular traits and of testicular traits with backfat thickness and 140-d body weight are presented in table 1 . Correlations among the testicular traits ranged from .45 to .88 . Correlations of backfat thickness with testicular traits were between .08 and .21. Body weight was significantly correlated with epididymis weight and testis length $(r=.50$ and .35 , respectively).

Correlations among concentrations of gonadotropins are presented in table 2 . The mean and maximum predicted $\mathrm{LH}$ concentrations were significantly correlated $(r=.74)$. The remaining correlations among the levels of gonadotropins ranged from -.15 to .27 .

Correlations between testicular traits and concentrations of gonadotropins are shown in table 3. Correlations between the mean concentration of $\mathrm{LH}$ and testicular traits ranged from .24 to .49 . Testicular development was more highly correlated with $\mathrm{LH}$ concentrations from 42 to $84 \mathrm{~d}$ of age than with LH concentrations from 98 to $140 \mathrm{~d}$. Correlations between maximum predicted $\mathrm{LH}$ concentrations and testis traits were between .19 and .42 . Correlations of age at maximum predicted $\mathrm{LH}$ concentration with testicular traits ranged from -.12 to -.26 . Testicular traits were correlated with the number of peaks $(r=.31$ to .43$)$ but not with the $\mathrm{LH}$ sample variance $(\mathrm{r}=-.14$ to -.01$)$. Correlations between the mean concentration of FSH and testicular traits ranged from -.20 to 19 .

The correlations of testicular traits and concentrations of gonadotropins with mean concentrations of steroids are presented in table 4. Correlations of $E_{2}$ concentrations with testicular traits ranged from .22 to .41 . Correlations of $\mathrm{T}$ concentrations with testicular traits were between .12 and .33. The correlations 
TABLE 1. CORRELATIONS AMONG TESTICULAR TRAITS AND OF TESTICULAR TRAITS WITH BODY WEIGHT AND BACKFAT THICKNESS ${ }^{a}$

\begin{tabular}{|c|c|c|c|c|c|c|c|}
\hline Item & $\begin{array}{l}\text { Testis } \\
\text { weight }\end{array}$ & $\begin{array}{l}\text { Epididymis } \\
\text { weight } \\
\text { (1) }\end{array}$ & $\begin{array}{l}\text { Testis } \\
\text { width } \\
\text { (2) }\end{array}$ & $\begin{array}{l}\text { Testis } \\
\text { length } \\
(3)\end{array}$ & $\begin{array}{l}\text { Percentage } \\
\text { spermb } \\
(4)\end{array}$ & $\begin{array}{l}\text { Percentage } \\
\text { lumen } b \\
(5)\end{array}$ & $\begin{array}{l}\text { Tubule } \\
\text { diameter }\end{array}$ \\
\hline $\begin{array}{l}\text { Testis weight } \\
\text { (1) } \\
(2) \\
(3) \\
(4) \\
(5)\end{array}$ & & $.65^{* *}$ & $\begin{array}{l}.88^{* *} \\
.63^{* *}\end{array}$ & $\begin{array}{l}.88 * * \\
.67 * * \\
.71 * *\end{array}$ & $\begin{array}{l}.76 * * \\
.53^{* *} \\
.71^{* *} \\
.68^{* *}\end{array}$ & $\begin{array}{l}.72^{* *} \\
.45^{* *} \\
.88^{* *} \\
.66^{* *} \\
.94^{* *}\end{array}$ & $\begin{array}{l}.80^{* *} \\
.59^{* *} \\
.90^{* *} \\
.86^{* *} \\
.80^{* *} \\
.75^{* *}\end{array}$ \\
\hline $\begin{array}{l}\text { Backfat thickness } \\
\text { Body weight }\end{array}$ & $\begin{array}{l}.08 \\
.13\end{array}$ & $\begin{array}{l}.21 \\
.50^{* *}\end{array}$ & $\begin{array}{l}.10 \\
.24\end{array}$ & $\begin{array}{l}.08 \\
.35^{*}\end{array}$ & $\begin{array}{r}.20 \\
-.12\end{array}$ & $\begin{array}{r}.21 \\
-.08\end{array}$ & $\begin{array}{l}.14 \\
.12\end{array}$ \\
\hline
\end{tabular}

${ }^{a}$ Correlations pooled within line and farrowing group ( 36 boars).

$b_{\text {Percentage }}$ sperm $=$ percentage of seminiferous tubules with active spermatogenesis. Percentage lumen $=$ percentage of seminiferous tubules with a lumen. Tubule diameter $=$ seminiferous tubule diameter.

${ }^{*} \mathrm{P}<.05$.

$* * \mathrm{P}<.01$.

between levels of gonadotropins and steroids were small and nonsignificant.

Correlations between LH concentrations from adjacent age periods ranged from -.05 to 48. Correlations between concentrations of FSH from adjacent ages from 42 to $84 \mathrm{~d}$ of age ranged from .27 to .80 and those from 98 to $140 \mathrm{~d}$ were between .43 and .84 . No relationship was found between FSH concentrations at 84 and $98 \mathrm{~d}$ of age, the time period during which FSH concentration rapidly increased. Correlations between concentrations of $\mathrm{T}$ from adjacent age periods ranged from .07 to .70 . A positive relationship was also found between concentrations of $E_{2}$ from adjacent sampling ages $(r=.09$ to .57$)$. The remaining correlations among concentrations of hormones at the same or at different ages were very small.

\section{Discussion}

The significant correlations between measures of testis size and percentage of tubules with active spermatogenesis suggest that boars with large testes are sexually more mature at $140 \mathrm{~d}$ of age and are producing greater numbers of sperm cells. Schinckel et al. (1983) reported correlations of approximately .56 between similar measures of testis size and percentage of

TABLE 2. CORRELATIONS AMONG CONCENTRATIONS OF GONADOTROPINSa

\begin{tabular}{|c|c|c|c|c|c|}
\hline Item & LH & (1) & (2) & (3) & (4) \\
\hline \multicolumn{6}{|l|}{ Maximum predicted } \\
\hline LH concentration (1) & $.74^{* *}$ & & & & \\
\hline \multicolumn{6}{|c|}{ Age at maximum predicted } \\
\hline LH concentration $(2)$ & -.10 & -.16 & & & \\
\hline \multicolumn{6}{|l|}{ Variance of the } \\
\hline LH samples (3) & $.27^{\dagger}$ & .14 & .08 & & \\
\hline No. of peaks (4) & .25 & .15 & -.08 & -.13 & \\
\hline FSH & .03 & .15 & -.09 & -.15 & -.09 \\
\hline
\end{tabular}

${ }^{a}$ Correlations pooled within line and farrowing group ( 36 boars). $\mathrm{LH}=$ mean concentration of luteinizing hormone from 42 to $140 \mathrm{~d}$ of age; no. of peaks = number of LH peaks observed from 42 to $140 \mathrm{~d}$ of age; FSH = mean concentration of follicle-stimulating hormone from 42 to $140 \mathrm{~d}$ of age.

$t_{\mathrm{P}<\mathrm{10}}$.

* $*$ P $<.01$. 
SCHINCKEL ET AL.

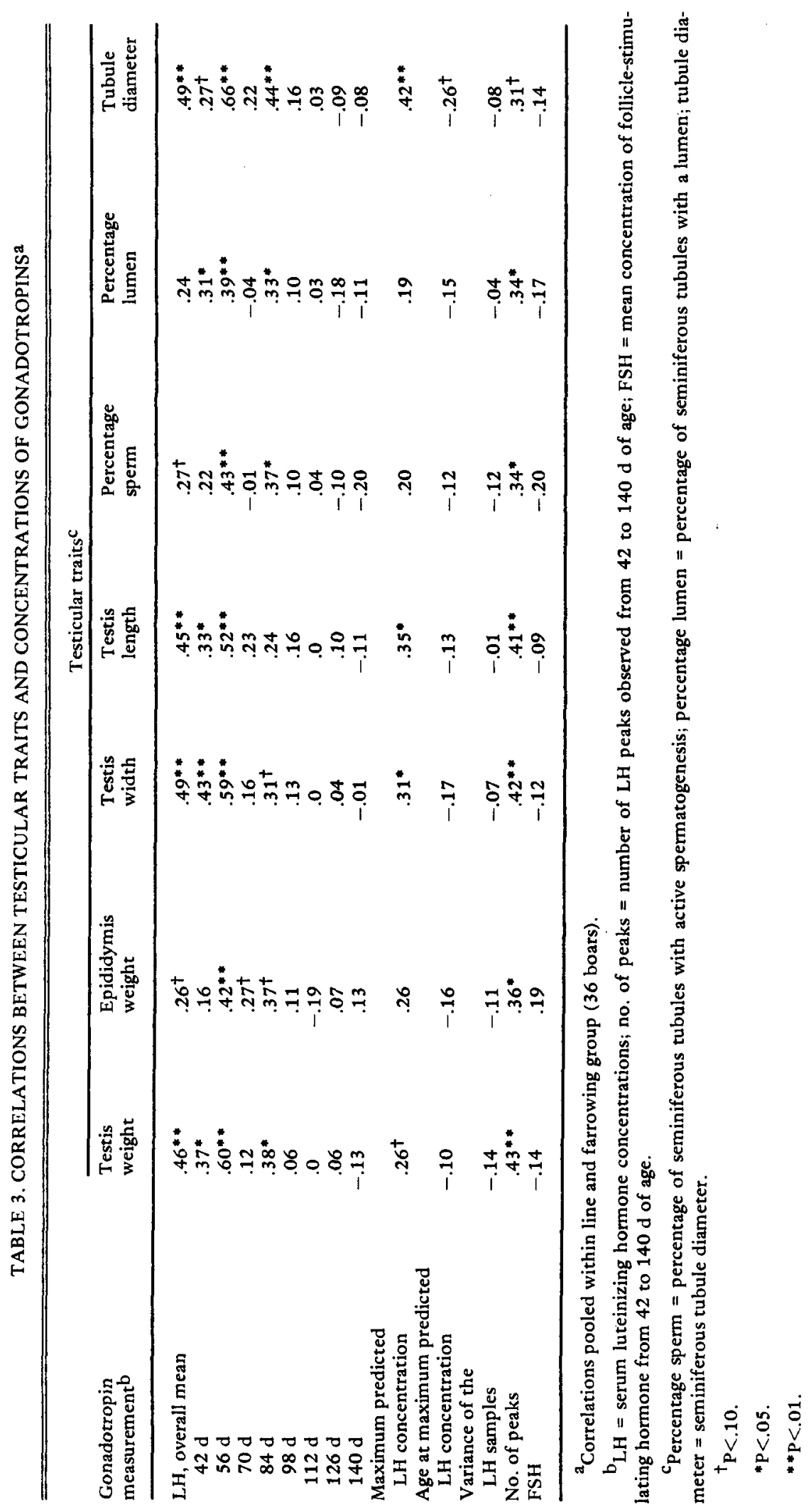


TABLE 4. CORRELATIONS OF TESTICULAR TRAITS AND CONCENTRATIONS OF GONADOTROPINS WITH MEAN CONCENTRATIONS OF STEROIDS ${ }^{a}$

\begin{tabular}{|c|c|c|}
\hline Itemb & Estradiol-17 $\beta$ & Testosterone \\
\hline Testis weight & $.39 * *$ & .20 \\
\hline Epididymis weight & $.41^{* *}$ & .33 \\
\hline Testis width & $.31^{\dagger}$ & .20 \\
\hline Testis length & $.30^{\dagger}$ & .18 \\
\hline Percentage sperm & $.37^{*}$ & .23 \\
\hline Percentage lumen & .22 & .23 \\
\hline Tubule diameter & $.40^{* *}$ & .12 \\
\hline LH concentration & .17 & -.04 \\
\hline \multicolumn{3}{|l|}{ Maximum predicted } \\
\hline L.H concentration & .11 & -.09 \\
\hline \multicolumn{3}{|c|}{ Age at maximum predicted } \\
\hline L.H concentration & -.23 & .18 \\
\hline \multicolumn{3}{|l|}{ Variance of the } \\
\hline LH samples & .23 & .08 \\
\hline No. of peaks & -.08 & .20 \\
\hline FSH & -.01 & .04 \\
\hline Testosterone & .22 & \\
\hline
\end{tabular}

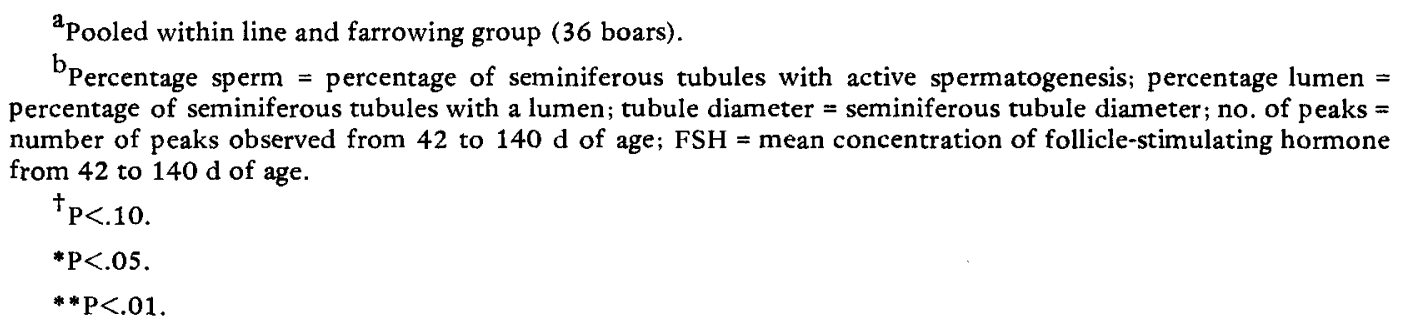

tubules with active spermatogenesis. Correlations between testis weight and testis sperm numbers in $210-$ to 225 -d-old boars have been reported to be in the range of .65 to .91 (Wilson et al., 1977; Fent, 1980; Neissen et al., 1982). In yearling bulls, correlations of scrotal circumference with sperm output and sperm concentration have been estimated to be .81 and .54 , respectively (Hahn et al., 1969; Knights et al., 1982).

Correlations of body weight with epididymis weight and testis length were significant. The correlation of body weight with testis weight ( $\mathrm{r}$ $=.13$ ) was smaller than those previously reported $(r=.5$ to .7 ; Allrich et al., 1982; Schinckel et al., 1983). The small, positive correlations found in this study between testis size and backfat thickness were similar to those found by Schinckel et al. (1983).

The majority of the correlations among levels of gonadotropins are small, suggesting that they are essentially independent. The observed correlation between the mean and maximum predicted LH concentrations is partially due to a part-whole relationship that exists between the traits.

The two measures of variability, $\mathrm{LH}$ sample variance and number of peaks, were expected to be positively correlated. However, the correlation was low $(-.13)$. The number of peaks is an estimate of the number of statistically significant releases of $\mathrm{LH}$, but may not be equal to the number of $\mathrm{LH}$ releases that have physiological significance. At present, the magnitude of LH pulses required for modification of testicular function in the boar is not known. The sample variance estimates dispersion more precisely than the number of peaks, but may not be as biologically descriptive.

Boars with larger, more mature testes tended to have higher LH concentrations during development. In rams, within line correlations ranging from .5 to .7 have been found between testis diameter and mean LH concentrations when blood samples were taken 3 to $6 \mathrm{wk}$ before the measurement of testis size (Carr and Land, 1975).

The concentrations of LH from 42 to $84 \mathrm{~d}$ of age were more highly correlated with testicular development than were LH concentrations 
from 98 to $140 \mathrm{~d}$. One possible explanation is that the increase in $\mathrm{LH}$ concentrations precedes the period of most rapid testicular development and that high LH concentrations from 42 to 84 $\mathrm{d}$ of age are indicative of boars with earlier and higher pubertal releases of $\mathrm{LH}$, resulting in more fully developed testes at $140 \mathrm{~d}$ of age. In the present study, boars reached their maximum LH concentrations between 84 and $112 \mathrm{~d}$ of age, but rapid testicular development did not occur in this line until 120 to $160 \mathrm{~d}$ (Schinckel et al., 1983). A pubertal rise in LH concentrations that preceded testicular growth by several weeks was also found in bulls and rams (Lee et al., 1976; Lincoln et al., 1977; Lacroix and Pelletier, 1979). These results suggest that to determine biological relationships, blood samples should be taken before the measurement of testis growth and that correlations between testis growth and LH concentrations obtained at the same age should be interpreted with caution.

The correlations between the number of $\mathrm{LH}$ peaks and testis size suggest that the number of LH peaks may be related to pubertal development. Results of research conducted with rams and bulls also support the importance of a pulsatile pattern of $\mathrm{LH}$ release. Prolonged pulsatile infusion of luteinizing hormonereleasing hormone (LHRH, 100 or $500 \mathrm{ng}$ $\mathrm{iv} / 2 \mathrm{~h}$ ) in intact rams during the nonbreeding season increased pulse frequency and mean concentrations of $\mathrm{LH}$ and resulted in increased growth of the testis (Lincoln, 1979). Also, ranks of breed means for age at puberty of rams and mean plasma $\mathrm{LH}$ concentrations, frequency of LH pulses and testis size were similar (Carr and Land, 1975).

Our results suggest that the variation among boars in testicular development and serum steroid concentrations cannot be explained by variation in FSH concentrations. Perhaps testicular growth and steroid production are not highly sensitive to normal physiological variation in FSH concentrations. Boars may vary in their sensitivity to FSH. Certainly, FSH plays a major role in pubertal development in other species. In the rat, FSH causes Leydig cell maturation, the conversion of $\mathrm{T}$ to $\mathrm{E}_{2}$ and the production of androgen-binding protein (Bartke et al., 1978; Dorrington et al., 1978). In hypophysectomized rams, FSH acts synergistically with LH to increase testis growth (Courot, 1970).
Boars with larger, more mature testes tended to have higher serum steroid concentrations during development. This relationship has at least two possible interpretations: (1) boars with larger testes at $140 \mathrm{~d}$ had larger testes with greater numbers of steroid-producing cells during development, or (2) boars with higher steroid concentrations are less sensitive to the negative feedback effects of $T$ and $E_{2}$ at the hypothalamo-hypophyseal axis, consequently their testicular growth occurs more rapidly. The magnitude of these correlations $(r=.18$ to .41$)$ suggests that variation in steroid concentrations is virtually independent of testis size.

\section{Literature Cited}

Allrich, R. D., R. K. Christenson, J. J. Ford and D. R. Zimmerman. 1982. Pubertal development of the boar: Testosterone, estradiol-17\%, cortisol and LH concentrations before and after castration at various ages. J. Anim. Sci. 55:1139.

Bartke, A., A. A. Hafiez, F. J. Bex and S. Dalterio. 1978. Hormonal interaction in regulation of androgen secretion. Biol. Reprod. 18:44.

Carr, W. R. and R. B. Land. 1975. Plasma luteinizing hormone levels and testis diameter of ram lambs of different breeds. J. Reprod. Fertil. 42:325.

Courot, M. 1970. Testicular development of hypophysectomized lambs after hormonal supplementation. Adv. Exp. Med. Biol. 10:355.

Dorrington, J. H., I. B. Fritz and D. T. Armstrong. 1978. Control of testicular estrogen synthesis. Biol. Reprod. 18:55.

Fent, R. W. 1980. Influence of breed on testicular and endocrine function of pubertal boars. M.S. Thesis. Oklahoma State Univ., Stillwater.

Hahn, J., R. H. Foote and G. E. Seidel, Jr. 1969. Testicular growth and related sperm output in dairy bulls. J. Anim. Sci. 29:41.

Knights, S. A., J. B. Gibb and R. L. Baker. 1982. Relationships among growth and fertility traits in yearling Angus bulls. J. Anim. Sci. 55(Suppl. 1): 152

Lacroix, A. and J. Pelletier. 1979. Short-term variations in plasma $\mathrm{LH}$ and testosterone in bull calves from birth to one year of age. J. Reprod. Fertil. 55:81.

Land, R. B. and W. R. Carr. 1979. Reproduction in domestic mammals. In: G. M. Shire (Ed.) Genetic Variation in Hormone Systems. PP 87-111. CRC Press, New York.

Land, R. B. and C. J. Lee. 1976. Testis growth: A possible genetic predictor of female reproductivity. Anim. Prod. 22:135 (Abstr.).

Lee, V.W.K., I. A. Cumming, D. M. deKrestser, J. K. Findlay, B. Hudson and E. J. Keogh. 1976. Regulation of gonadotrophin secretion in rams from birth to sexual maturity. I. Plasma LH, FSH and testosterone levels. J. Reprod. Fertil. 46:1.

Lincoln, G. A. 1979. Use of a pulsed infusion of luteinizing hormone releasing hormone to mimic seasonally induced endocrine changes in the ram. J. Endocrinol. 83:251.

Lincoln, G. A., M. J. Peet and R. A. Cunningham. 
1977. Seasonal and circadian changes in the episodic release of follicle stimulating hormone, luteinizing hormone and testosterone in rams exposed to artificial photoperiods. J. Endocrinol. $72: 337$.

Nelssen, J. L., D. L. Davis, J. V. Craig and R. H. Hines. 1982. Reproductive development in young boars exposed to sexually mature, nonpregnant sows and gilts. Theriogenology 17:545.

Schinckel, A. P., R. K. Johnson and R. J. Kittok. 1984. Testicular development and endocrine characteristics of boars selected for either high or low testis size. J. Anim. Sci. 58:675.
Schinckel, A. P., R. K. Johnson, R. A. Pumfrey and D. R. Zimmerman. 1983. Testicular growth of different genetic lines and its relationship to reproductive performance. J. Anim. Sci. 56:1065.

Wilson, E. R., R. K. Johnson and R. P. Wettemann. 1977. Reproductive and testicular characteristics of purebred and crossbred boars. J. Anim. Sci. 44:939.

Wolfe, H. G., A. Bartke, A. Amador, M. van Sickel, S. Dalterio and D. Brown. 1981. Testicular function in strains of mice selected for differences in gonadotropin-induced ovulation rate. J. Endocrinol. 90:367. 